\title{
Polidentát tripodális ligandumok biomimetikus fémkomplexei
}

\author{
GAJDA Tamás ${ }^{\mathrm{a},{ }^{*},}$, SZORCSIK Attila ${ }^{\mathrm{b}}$, DANCS Ágnes ${ }^{\mathrm{a}}$ és MATYUSKA Ferenc ${ }^{\mathrm{a}}$ \\ a Szegedi Tudományegyetem, Szervetlen és Analitikai Kémiai Tanszék, Dóm tér 7, 6721 Szeged, Magyarország \\ ${ }^{b}$ MTA-SZTE Bioszervetlen Kémiai Kutatócsoport, Dóm tér 7, 6721 Szeged, Magyarország
}

\section{Bevezetés}

A natív enzimekhez hasonló aktivitással, szelektivitással és/vagy működési mechanizmussal rendelkező kis molekulatömegű fémkomplexek vizsgálata mind elméleti (a metalloenzimek müködésének jobb megismerése), mind gyakorlati (bioutánzó katalizátorok/ mesterséges enzimek) szempontból értékes eredményeket szolgáltathat. A Szegedi Tudományegyetem Bioszervetlen Kémiai kutatócsoportjában (TTIK, Szervetlen és Analitikai Kémiai Tanszék) a kis molekulatömegü biomimetikus katalizátorok fejlesztése 15-20 éves múltra tekinthet vissza. Az első időkben többnyire alkoxo-hidas kétmagvú komplexeket, később multihisztidin peptidek fémkomplexeit vizsgáltuk, de a tripodális (multipodális) ligandumok munkánk során mindvégig jelen voltak.

A tripodális vegyületek számos elönyös tulajdonsággal rendelkeznek a lineáris ligandumokkal szemben. A kelátgyürük nagyobb száma és az ún. preorganizált szerkezet, ami alatt a ligandum korlátozott konformációs szabadságát szokás érteni, jelentősen növeli a komplex stabilitását. Másrészt a tripodális ligandumokra jellemző faciális koordináció szabad teret enged a szubsztrát megkötődésének, ami a legtöbb fémion-katalizált folyamat meghatározó lépése. A lábak megfelelő derivatizálása ugyanakkor egy olyan moduláris rendszer kialakítását teszi lehetővé, amelyben viszonylag könnyen változtatható a ligandum donorcsoportjainak száma/minősége, így annak fémion affinitása, vagy a kialakuló komplex szerkezete. De további funkciók kiépítése is lehetővé válik: (i) pl. további fémion megkötése, ami a többmagvú aktív centrumokra jellemzően lehetőséget teremt a fémionok kooperációjára a katalitikus ciklusban, (ii) valamint beépíthetőek olyan molekularészek, melyek elősegítik a szubsztrát megkötését, vagy annak aktiválását (pl. sav/bázis katalízis révén).

A fentieknek megfelelően munkánk során előállítottuk és vizsgáltuk néhány egyszerü tripodális platform (cisz,cisz-1,3,5-triamino-ciklohexán, trisz(2-aminoetil) amin, nitrilo-triecetsav) különbözőképpen szubsztituált származékát. Célunk az volt, hogy feltérképezzük a szubsztituensek számának és minőségének hatását réz(II)- és cink(II)-komplexeik összetételére, szerkezetére és termodinamikai stabilitására. Vizsgáltuk továbbá, hogy ezek a sajátságok hogyan befolyásolják a fémkomplexek hidrolitikus és redoxi reakciókra gyakorolt katalitikus hatását.

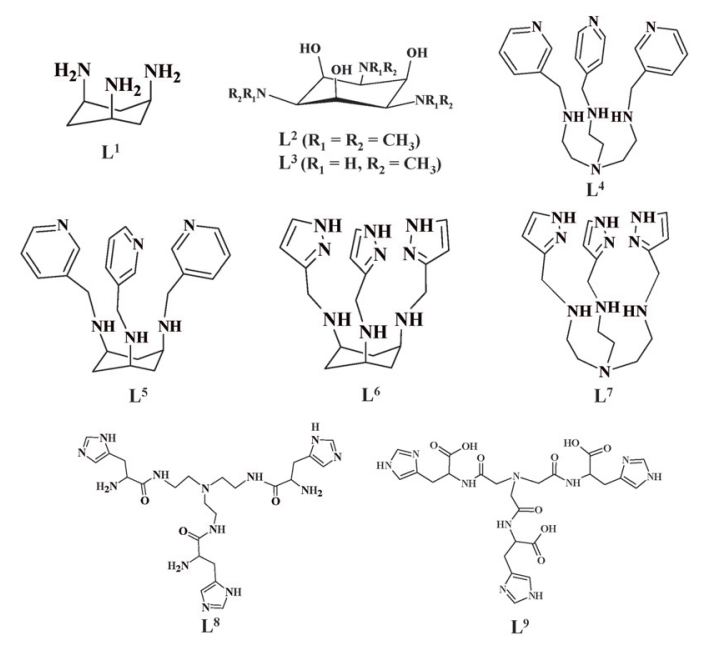

1. Séma A jelen dolgozatban tárgyalt ligandumok sematikus szerkezete

2. A cisz,cisz-1,3,5-triamino-ciklohexán (tach) és egyszerú származékainak fémkomplexei

A tach $\left(\mathbf{L}^{\mathbf{1}}, 1\right.$. séma) egy jól ismert, faciális koordinációt eredményező tripodális ligandum. ${ }^{1}$ Minthogy a fémionhoz kötődő hidroxidion, mint nukleofil reaktáns, a hidrolázok funkcionális modelljeinek fontos eleme, a $\mathrm{CuL}^{\mathbf{1}}(\mathrm{OH})$ komplex a hidrolitikus reakciók viszonylag aktív katalizátora. Azonban a $2 \mathrm{CuL}^{\mathbf{1}}(\mathrm{OH})=\mathrm{Cu}_{2} \mathbf{L}_{2}{ }_{2}(\mathrm{OH})_{2}$ dimerizációs egyensúlyban $(\mathrm{K}=5750)^{2}$ képződő inaktív dimer miatt a rendszer összességében kis hatékonyságú. Azonban az erősen kötődő szubsztrátok koordinációja megakadályozhatja az inaktív dimer komplex képződését. Ennek megfelelően a $\mathrm{Cu}^{\mathbf{1}}$ komplex hatékonyan képes elősegíteni a nem-aktivált dipeptidek (DP) hidrolízisét. $^{2}$ Eredményeink szerint a pH 7-10 tartományban képződő $\mathrm{CuL}^{1}$ (DP) vegyes komplex felelös a tapasztalt hidrolitikus hatásért. A DP = Gly-Gly. Gly-Leu és Leu-Gly esetekben a hidrolízis a hidroxidion ill. víz nukleofil támadása révén valósul meg (a folyamat $\mathrm{pH}$-függő), s a fémion szerepe csak a karbonil oxigén Lewis-sav aktiválása. Ugyanakkor a Gly-Ser hidrolízise előzőeknél jóval gyorsabb, és a hidrolízis sebessége alig függ a pH-tól. Ez a viselkedés a szerin hidroxilcsoportjának, valószínűleg a réz(II) által elősegített, intramolekuláris nukleofil támadásával magyarázható (1. ábra). A rendszer érdekessége, hogy az 'aktív komplex-szubsztrát' adduktumot a Gly-Gly esetében egykristály formában is sikerült kinyerni, s a röntgen vizsgálatok a dipeptid kétfogú $\left\{\mathrm{NH}_{2}, \mathrm{C}=\mathrm{O}\right\}$ koordinációját

* Gajda Tamás. Tel.: 06-62-544335; fax: 06-62-544340; e-mail: gajda@chem.u-szeged.hu

123. évfolyam, 2. szám, 2017. 
bizonyították. A hidrolízis pH 10 felett már nem játszódik le, összhangban a vegyeskomplexben kötött dipeptid amidcsoportjának fémionindukált deprotonálódásával.

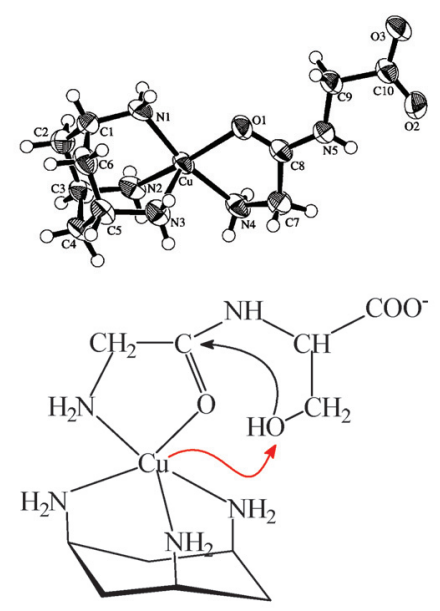

1. Ábra $\mathrm{A}\left[\mathrm{CuL}^{1}(\mathrm{Gly}-\mathrm{Gly})\right]^{+}$komplex röntgenszerkezete és a Gly-Ser dipeptid $\mathrm{CuL}^{1}$ komplex által elősegített hidrolízisének javasolt mechanizmusa $^{2}$

A hidrolázok/nukleázok legtöbbjének aktív centrumában két, esetleg három fémion található, melyek jól szervezett együttmüködése biztosítja a hatékony hidrolízist. ${ }^{3}$ Így a mesterséges foszforsav-diészterázok (nukleázok) kifejlesztésének kézenfekvő stratégiája lehet kétmagvú komplexek kialakítása. Ez elönyös lehet a szubsztrát hatékonyabb megkötése, annak ún. dupla Lewis-sav aktiválása, a két fémion között hídként kötődő $\mathrm{PO}_{4}$-tetraéderben indukált feszülés megjelenése, valamint a távozó csoport stabilizálása szempontjából.

A tach ligandummal rokon 1,3,5-triamino-1,3,5-trideoxicisz-inozitol és ennek N-metil-származékai (tdci $\left(\mathbf{L}^{2}\right)$, tmci $\left(\mathbf{L}^{\mathbf{3}}\right)$ 1. séma) számos, a fémion koordináció szempontjából kedvező tulajdonsággal rendelkeznek. ${ }^{4} \mathrm{E}$ ligandumok három ekvivalens $\left\{\mathrm{O}_{\mathrm{ax}} \mathrm{N}_{\mathrm{eq}} \mathrm{O}_{\mathrm{ax}}\right\}$ faciális kötőhellyel bírnak, melyek egy-, két- ill. hárommagvú komplexek kialakulását is lehetővé teszik. Valóban, egyensúlyi vizsgálataink szerint a réz(II)- $\mathbf{L}^{2}$ rendszerben a $\mathrm{pH}$-tól ill. a fém/ligandum aránytól függően, különböző protonáltsági állapotú egy-, két- ill. hárommagvú komplexek képződnek, ${ }^{5}$ melyekben alkoxo-hidak kötik össze a fémionokat. Meghatároztuk, egy az oldatban levő komplexek aggregációjával létrejövő ötmagvú, $\left.\quad \mathrm{Cu}_{5}\left(\mathbf{L}^{2} \mathrm{H}_{-2}\right)\left(\mathbf{L}^{2}\right)_{2}(\mathrm{OH})_{2}\left(\mathrm{NO}_{3}\right)_{2}\right]\left(\mathrm{NO}_{3}\right)_{4} 6 \mathrm{H}_{2} \mathrm{O}$ összetételü komplex kristályszerkezetét (2. ábra), amely egy igen érdekes $\mathrm{Cu}_{5} \mathrm{O}_{6}$ klasztert tartalmaz. A komplex azonos ligandumhoz kötődő fémionjait alkoxo-hidak kötik össze, ami megerősíti az oldatfázisban képződő komplexek szerkezetére vonatkozó megállapításainkat. Másrészt, az alkoxo-hidas fémcent-rumokban a fémionok egymástól 3,63-3,78 A távolságban helyezkednek el, ami hasonlatos a kétmagvú metallo-foszfoészterázok aktív centrumára jellemző fémion szeparációra. ${ }^{3}$ Mindezen sajátságok alapján a többmagvú komplexek hatékony foszfoészteráz modelleknek ígérkeztek.

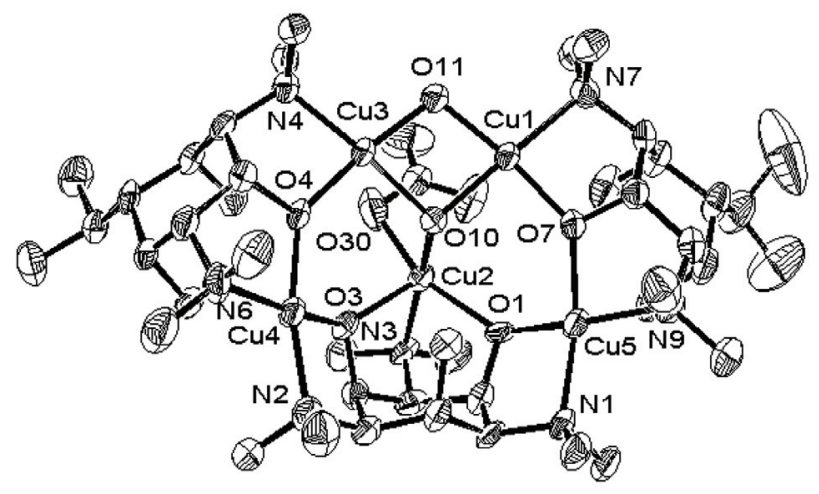

2. Ábra $\mathrm{A}\left[\mathrm{Cu}_{5}\left(\mathbf{L}^{2} \mathrm{H}_{22}\right) \mathbf{L}_{2}^{2}(\mathrm{OH})_{2}\left(\mathrm{NO}_{3}\right)_{2}\right]^{4+}$ kation ORTEP ábrázolása ${ }^{5}$

A több egy-, két- ill. hárommagvú $\mathrm{Cu}(\mathrm{II})-\mathbf{L}^{2}$ komplex képződése miatt a tapasztalható hidrolitikus hatás várhatóan erősen függ a közeg pH-jától és a fém/ligandum aránytól. Valóban, a komplexeknek a bisz-4-nitrofenil-foszfát (bnpp, DNS modell) hidrolízisére gyakorolt hatása maximum-görbe szerint változik, mind a $\mathrm{pH}$, mind a fém/ligandum arány függvényében (3 ábra).
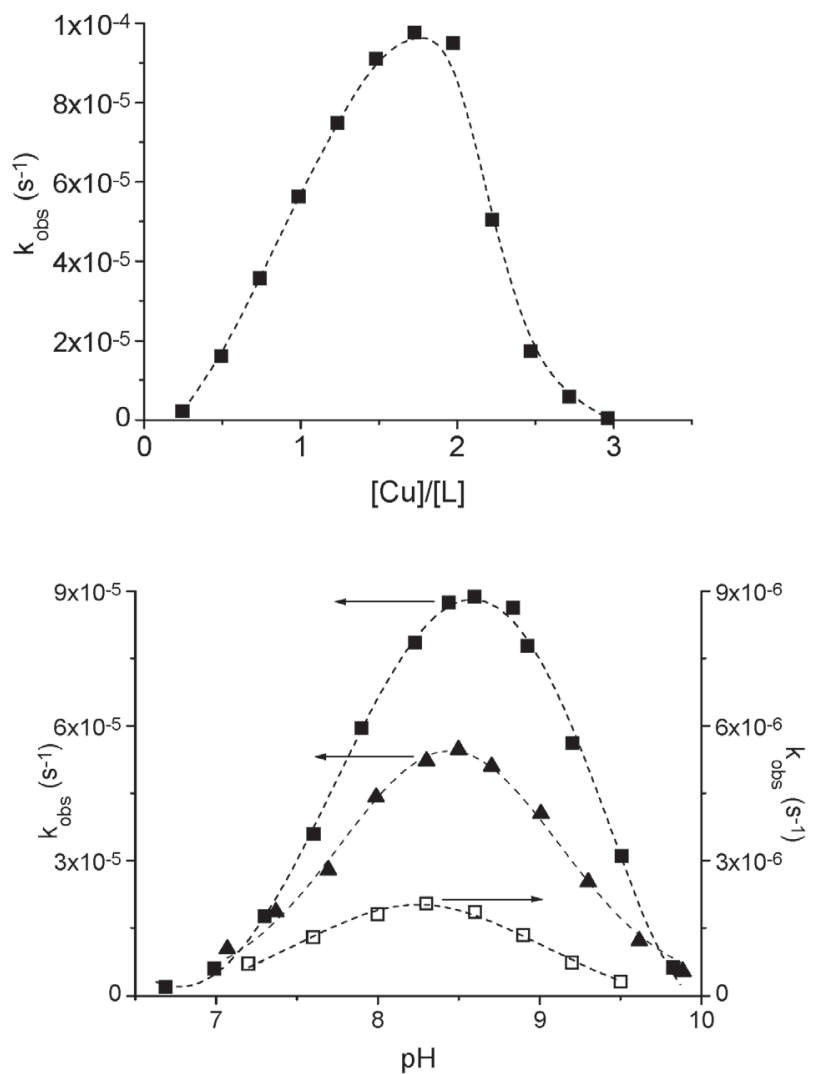

3. Ábra A bnpp hidrolízisének függése a fém/ligandum aránytól (fent, $\mathrm{pH}$ $\left.=8,60,\left[\mathbf{L}^{2}\right]=0,46 \mathrm{mM}, \mathrm{T}=298 \mathrm{~K}\right) ; \mathrm{A}$ bnpp $(\mathbf{\square})$, az npp ( $\square$ ) ill. a dnpep $(\mathbf{\Delta})$ hidrolízisének $\mathrm{pH}$-függése a réz(II)- $\mathbf{L}^{2}$ rendszerben (lent, $\left.[\mathrm{Cu}]=2\left[\mathbf{L}^{2}\right], \mathrm{T}=298 \mathrm{~K}\right) . \mathbf{\square}, \mathbf{A}:[\mathrm{Cu}]=0,88 \mathrm{mM}, \mathrm{\square}:[\mathrm{Cu}]=3 \mathrm{mM}$. 
Figyelembe véve oldategyensúlyi eredményeinket, a tapasztalt hidrolitikus hatás a kétmagvú $\mathrm{Cu}_{2} \mathrm{H}_{-3} \mathbf{L}^{2}$ komplexhez rendelhetö. Bár e komplex említésre méltó foszfomonoészteráz aktivitást is mutat a 4-nitrofenilfoszfáttal (npp) szemben (3. ábra), azonos körülmények között a bnpp hidrolízisének sebessége $\sim 150$-szer nagyobb. Azaz a komplex hidrolitikus hatása szelektív a foszforsav-diészterekre. Optimális körülmények között 4 mM kétmagvú komplex 35 milliószorosára gyorsítja fel a bnpp autohidrolízisét. Az aktív komplex javasolt szerkezete (4. ábra) alkoxo-hidas fémcentrumot és két terminális hidroxidiont tartalmaz. A komplex kiemelkedő hatékonysága a bnpp hidrolízise során bifunkciós mechanizmussal, a két fémion által biztosított ún. dupla Lewis-sav aktiválással és a fémhez kötött hidroxidion direkt nukleofil katalízisével értelmezhető.

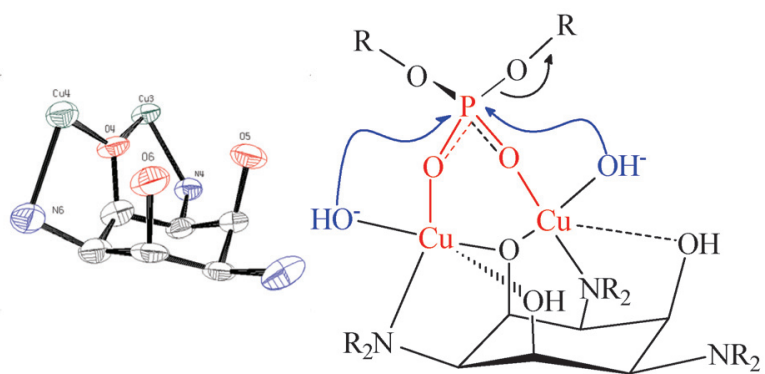

4. Ábra Az ötmagvú komplex egy fragmense és a bnpp hidrolízis javasolt mechanizmusa

Fenti kétmagvú komplex az ún. nem aktivált foszfoészterek hidrolízisét is képes elősegíteni, 2,5 mM-os koncentrációban 26000-szeresére gyorsítja fel a cAMP autohidrolízisét. ${ }^{6}$

Az irodalomból jól ismert, hogy számos foszfoészteráz (pl. bíborsav foszfatáz, protein foszfatáz 1 ill. 2B) tartalmaz vegyesmagvú aktív centrumot, ${ }^{3}$ amelyekben a két fémion eltérő kémiai sajátságai hasznosulnak. A tdci biner rendszereinek tanulmányozása során felvetődött a kérdés, hogy a két alkalmazott fémion (réz(II) és cink(II)) együttes jelenléte eredményez-e sebességnövekedést a ciklikus nukleotidok (vagy dinukleotidok) hidrolízisében. ${ }^{7}$ Eredményeink szerint 2,5 $\mathrm{mM}$ koncentrációjú vegyes-magvú terner komplex 120000-szeresére képes felgyorsítani a cAMP autohidrolízisét, azaz kb. ötször (negyvenszer) hatékonyabb, mint az analóg biner réz (cink) kétmagvú komplex. Ez a megnövekedett hatékonyság egy

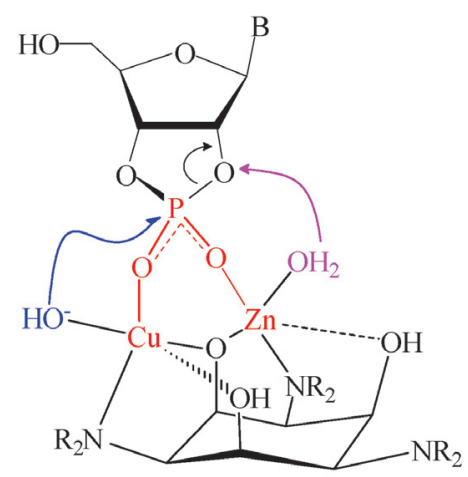

5. Ábra A vegyesmagvú $\mathrm{Cu}, \mathrm{Zn}$-komplex által katalizált cAMP hidrolízis javasolt mechanizmusa. az 5. ábrán megadott trifunkcionális mechanizmussal értelmezhető: (i) dupla Lewis-sav aktiválás, (ii) a réz(II)-hez kötött $\mathrm{OH}^{-}$-csoport általános bázis, valamint (iii) a cink(II)-hez kötött vízmolekula általános sav katalízise (távozó-csoport stabilizálás).

Végül említést érdemel, hogy az egyszeresen metilezett aminocsoportokat tartalmazó tmci ligandum $\left(\mathbf{L}^{3}, 1\right.$. séma ) a korábban tárgyalt tdci-hez nagyon hasonló egy-, két- és hárommagvú réz(II) komplexeket képez. Ugyanakkor a tdci analóg kétmagvú komplexével ellentétben katalitikus hatása szelektív a foszforsav-monoészterek hidrolízisére. ${ }^{8}$ Míg a $\mathrm{Cu}_{2} \mathrm{H}_{-3} \mathbf{L}^{2}$ komplex 150-szer gyorsabb hidrolízisét eredményezi a bnpp-nek mint az npp-nek, addig az analóg tmci komplex mintegy 2500-szor hatékonyabb a foszforsav-monoészter npp hidrolízisének elősegítésében. Bár ennek a látványos eltérésnek a pontos oka ismeretlen, fenti tapasztalat rávilágít a fémcentrumok környezetében található nem koordinálódó csoportok sztérikus hatásának alapvető jelentőségére.

\section{A cisz,cisz-1,3,5-triamino-ciklohexán (tach) és a trisz(2- aminoetil)amin (tren) N-szubsztituált származékainak fémkomplexei}

A Bevezetésben említetteknek megfelelően a tripodális ligandumok lábainak megfelelő derivatizálása egy olyan moduláris rendszer kialakítását teszi lehetővé, amelyben változtatható a ligandum fémion affinitása (donor-csoportjainak száma/minősége), valamint további fémkötö-helyek beépítése révén többmagvú komplexek állíthatóak elő. Ebből a célból munkánk során a tach és tren tripodális platformok jónéhány N-szubsztituált származékát állítottuk elő, melyek közül jelen publikációban négy ligandum fog említésre kerülni.

Érdekes összehasonlításra ad lehetőséget a tren3pir $\left(\mathbf{L}^{4}\right)$ és tach3pir $\left(\mathbf{L}^{\mathbf{5}}\right)$ ligandumok koordinációs sajátságai. $\mathrm{E}$ ligandumok viszonylag egyszerü koordinációs kémiai sajátsággal bírnak, hiszen a piridin és az amino-nitrogének nem képesek kelátgyürü kialakítására (vagyis ugyanazon fémionhoz kötődni). Ennek ellenére jól példázzák az ilyen moduláris rendszerekkel elérhető egyszerü sajátságokat. Bár a piridin-nitrogének elvileg alkalmasak további fémion(ok) megkötésére, oldatfázisban mindkét ligandum csak egymagvú komplexeket képez ( $\mathbf{L}^{4}$ esetén kristályos formában izoláltunk egy $2 / 1$ réz(II)/ligandum arányú 3D polimert).
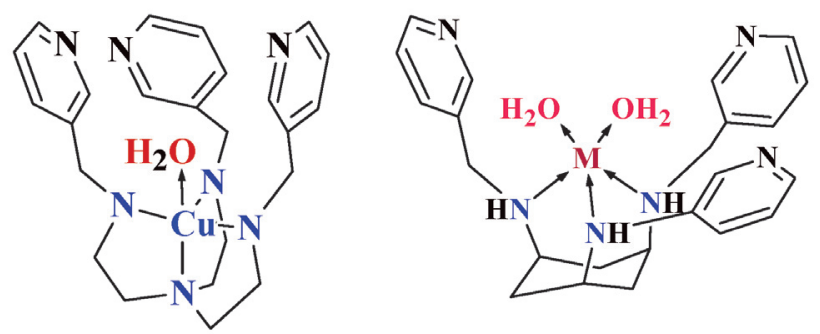

6. Ábra $\mathrm{A} \mathrm{Cu}^{4}$ és $\mathrm{CuL}^{5}$ komplexek sematikus szerkezete 
Vizes oldatban az $\mathbf{L}^{4}$ ligandum réz(II) komplexeinek mindegyikében a tren alegység négy nitrogénje koordinálja a fémiont. E komplexek trigonális bipiramisos szerkezetűek (6. ábra), amint azt jellegzetes látható és ESR spektrumuk is bizonyítja. Az ötödik pozícióban kötődő vízmolekula $\mathrm{pH} 8$ felett deprotonálódik. A piridingyürük sztérikus hatása miatt ez az ötödik koordinációs pozíció nagyobb ligandumok számára nehezen hozzáférhető, így ezek a komplexek nem rendelkeznek számottevő enzimutánzó hatással. Az analóg $\mathrm{CuL}^{\mathbf{5}}$ komplex azonban jóval nyitottabb koordinációs szférával rendelkezik (6. ábra). A fémion környezete nagyon hasonló a tach platform $\mathrm{Cu}^{\mathbf{1}}$ komplexéhez (1. ábra). Jelentős különbség azonban, hogy míg a $\mathrm{CuL}^{1}$ komplex komplex deprotonálódása egy dihidroxo-hidas dimert eredményez, addig piridingyürük sztérikus hatása miatt $\mathrm{Cu}^{\mathbf{5}}$ komplex deprotonálódása egymagvú vegyes hidroxo komplexeket eredményez, ami igéretes a hidroláz enzimek funkcionális modellezése szempontjából. Valóban, eredményeink szerint a $\mathrm{CuL}^{\mathbf{5}}(\mathrm{OH})$ komplex hatékonyan képes elősegíteni a foszforsav-diészter bnpp hidrolízisét, és az észlelt katalitikus hatás egyértelmüen a monohidroxo komplexhez rendelhető. Ez érthető is, ha meggondoljuk, hogy a víz ebben a komplexben könnyen lecserélhető a szubsztrátra, és a fémionhoz kötött hidroxidion nukleofil támadása indítja el a hidrolízist (7. ábra).

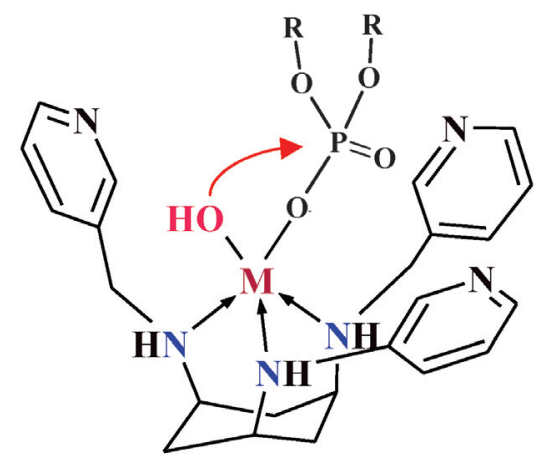

7. Ábra $\mathrm{A} \mathrm{CuL}^{5}(\mathrm{OH})$ komplex által katalizált bnpp hidrolízis javasolt mechanizmusa.

A következő példa két pirazol-származék $\left(\mathbf{L}^{6}, \mathbf{L}^{7} 1\right.$. séma) sajátságait hasonlítja össze. A tripodális platformok ebben az esetben is a tren és a tach voltak. A ligandumok szekunder aminocsoportjai és a gyürü-nitrogének itt már képesek kelát pozícióban kötődni a fémionokhoz, ami jelentösen növeli az ML komplexek stabilitását az alapvegyületekhez (tach, tren) képest. A tren-származéknál a trigonális bipiramisos szerkezet miatt egyetlen, a tach-származéknál fémiontól függően 2-3 gyürünitrogén koordinációja valósul meg. A 8. ábra $\mathbf{L}^{\mathbf{6}}$ ligandum cink(II) komplexének röntgenszerkezetét mutatja, amelyben a ligandum 6 donorcsoportjával kötődik a fémionhoz. A ábrából ugyanakkor az is kiderül, hogy a pirazol-gyürük nem koordinálódó nitrogénjei itt már tényleges lehetőséget biztosítanak további fémion megkötésére. Ennek megfelelően $\mathbf{L}^{6}$ ligandum réz(II) jelenlétében két egymagvú és három különböző protonáltsági állapotú hárommagvú komplexet képez ( 9 . ábra). A 9.a ábra jól példázza a négyzetes piramisos

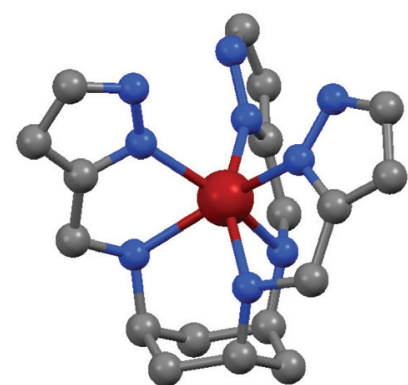

8. Ábra A $\mathrm{ZnL}^{5}$ komplexek szerkezete

szerkezetü $\mathrm{CuL}^{6}$ komplexnek a pirazol-gyürük koordinációja miatti kitüntetett stabilitását. Az 1/1 rendszerben pH 6-nál kék színü oldat magasabb pH-n vörösbor színűvé válik, ami a 4-500 nm-nél jelentkező intenzív töltésátviteli sávoknak köszönhető (9.c ábra). Ugyanezen sávok 3/2 fém/ligandum aránynál már pH 5-7 körül kialakulnak (9.d ábra), és egyértelmúen a hárommagvú fémkomplexek képződéséhez rendelhetőek. Figyelembe véve a ligandum szerkezetét is, ezek a deprotonálódás során kialakuló töltésátviteli sávok pirazolát-hidas többmagvú fémcentrumok kialakulását jelzik.
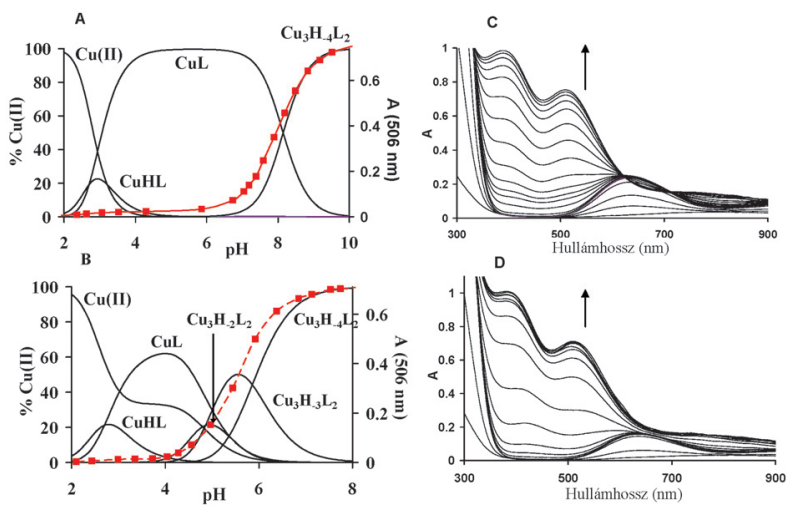

9. Ábra $\mathrm{A} \mathrm{Cu}(\mathrm{II})-\mathrm{L}^{6}$ 1:1 (A) és 3:2 (B) rendszerek eloszlásgörbéi és az 506 nm-nél mérhető fényelnyelés pH-függése, valamint a $\mathrm{Cu}(\mathrm{II})-\mathbf{L}^{\mathbf{6}} 1: 1$ (C) and 3:2 (D) rendszerek pH-függő UV-Vis spektrumai

A négyszeresen deprotonált hárommagvú komplex meglehetősen egyedi röntgenszerkezete (10. ábra) igazolja ezt a feltételezést. A lineárisan elhelyezkedő három rezet négy pirazoláthíd köti össze, a $\mathrm{Cu}-\mathrm{Cu}$ távolságok $3.8 \AA$ körüliek. A két szélső réz(II) a Jahn-Teller torzulás következtében megnyúlt négyzetes piramisos szerkezetű. A középső rézhez négy pirazolát-gyürü kötődik összenyomott tetraéderes geometria szerint.

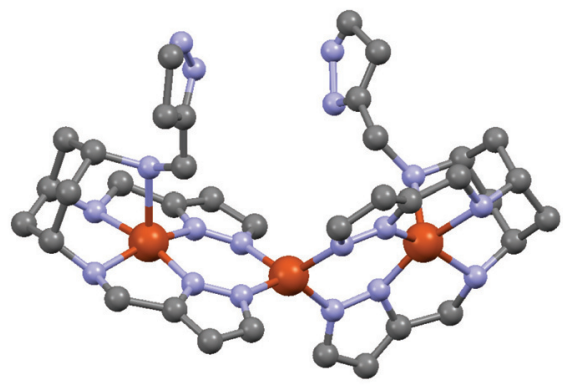

10. Ábra $\mathrm{A}\left[\mathrm{Cu}_{3}\left(\mathrm{H}_{?_{2}} \mathbf{L}^{6}\right)_{2}\right]^{2+}$ komplex kation szerkezete 
A $\quad\left[\mathrm{Cu}_{3}\left(\mathrm{H}_{22} \mathbf{L}^{\mathbf{6}}\right)_{2}\right]^{2+}$ komplex domináns megjelenése ekvimoláris oldatokban igen nagy termodinamikai stabilitásra utal (a kiindulási $\mathrm{CuL}^{\mathbf{6}}$ komplex is nagy stabilitású, ráadásul a hárommagvú komplex képződése egy kötött ligandum felszabadulásával jár). A folyamatban két egymagvú komplex oly módon aktivál/pozícionál négy pirazol-gyürüt, hogy egy nagy affinitású harmadik rézkötőhely képződik. Azaz a hárommagvú komplex képződése alloszterikusan kontrollált a két szélső réz és a pH által.

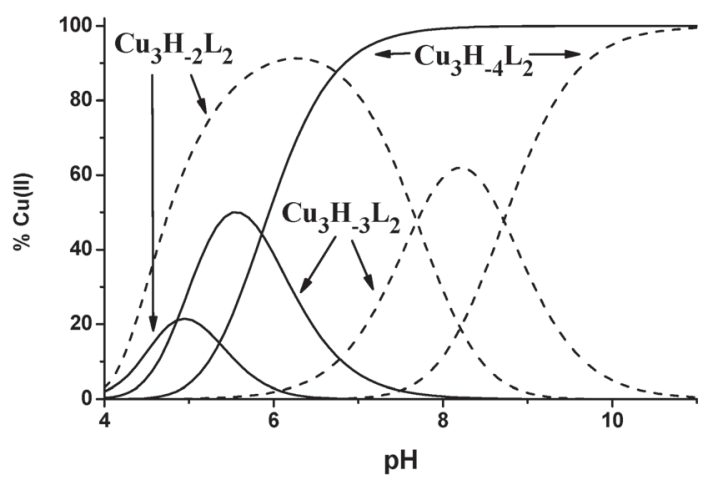

11. Ábra A hárommagvú komplexek eloszlásgörbéi a $\mathrm{Cu}(\mathrm{II})-\mathbf{L}^{6}$ (folytonos vonal) és a $\mathrm{Cu}(\mathrm{II})-\mathbf{L}^{7}$ (szaggatott vonal) rendszerekben $3 / 2$ fém/ligandum arány esetén.

$\mathrm{Az}$ analóg tren-alapú $\mathbf{L}^{7}$ ligandum hasonló koordinációs sajátsággal bír. Ebben az esetben is képződnek hárommagvú komplexek, viszont jelentősen eltér azok relatív stabilitása (11. ábra). Mivel ebben az esetben az egymagvú $\mathrm{Cu}^{7} \mathbf{L}^{7}$ komplex trigonális bipiramisos szerkezetü, az két szabad (nem koordinálódó) pirazol-gyürüt is tartalmaz. Emiatt a kétszer deprotonált hárommagvú komplex kitüntetett stabilitással bír. Egyrészt mert már két pirazolát-híd kialakulása esetén is elegendő donorcsoport áll rendelkezésre a középső réz erős kötődéséhez, másrészt mert a következő deprotonálódások a szélső rezek geometriaváltását idézik elő. Ilyen módon a tripodális platformtól függően az egyébként hasonló összetételü három és négy pirazolát-hidat tartalmazó hárommagvú komplexek képződése két-három pH egységgel tolódik el (11. ábra).

E ligandumok segítségével a dioxigént aktiválni képes oxidációs katalizátorokat szerettünk volna előállítani. Ennek érdekében vizsgáltuk komplexeink pirokatechin oxidáz aktivitását a széles körben használt di-terc-butilpirokatechin $\left(\mathrm{H}_{2} \mathrm{dtbc}\right)$ modell szubsztrát segítségével, aminek képződése könnyen követhető a termék kinon (dtbq) 400 nm-nél jelentkező elnyelési sávja alapján. A dtbq vízben rosszul oldódik, ezért $50 \%$ etanol-víz elegyben dolgoztunk, és az autooxidációt minden esetben korrekcióba vettük.

Vizsgálataink szerint az egymagvú CuL komplexek egyáltalán nem, a hárommagvú komplexek viszont igen hatékonyan képesek a $\mathrm{H}_{2} \mathrm{dtbc}$ oxidációját elősegíteni. A két ligandum hárommagvú komplexeinek képződésére vonatkozó fent említett eltérések a kinetikai sajátságokban is megmutatkoznak. A pirokatechin oxidáz aktivitás mindkét rendszerben maximum görbe szerint változik, viszont az optimális pH két egységgel eltér (12. ábra). A tren-alapú ligandum esetén tapasztaltuk a magasabb pH-optimumot, ami megfelel annak, hogy ennél a ligandumnál a háromszorosan deprotonált komplex képződése is eltolódik a magasabb pH-k felé (11. ábra). Azaz a $\mathrm{H}_{2} \mathrm{dtbc}$ oxidációja a fémionok koordinációs környezete, végső soron a tripodális platform által meghatározott és ennek révén szabályozható is.

Ugyanakkor, az optimális pH-n mindkét rendszer kiemelkedő és közel azonos pirokatechin oxidáz aktivitással bír. Kinetikai eredményeink a 13. ábrán megadott egyszerüsített mechanizmussal írhatóak le. A hárommagvú komplexek közül

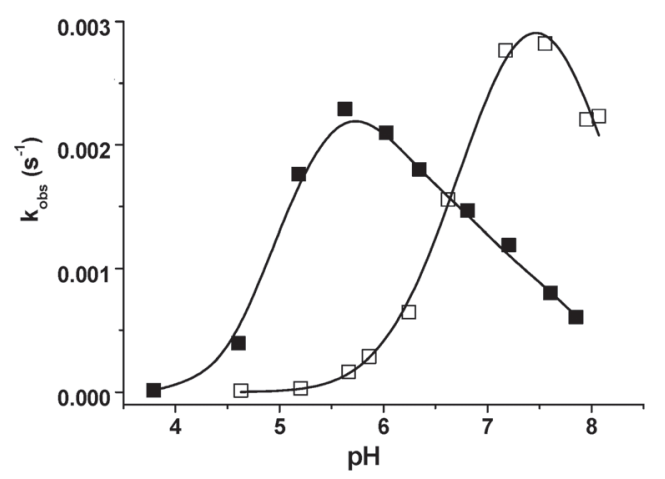

12. Ábra A dtbc oxidáció sebességének pH függése a réz(II)- $\mathbf{L}^{6}$ () és a réz(II)-L $\mathbf{L}^{7}$ () 3/2 fém/ligandum arányú rendszerekben $50 \%$ EtOH/víz elegyben $\left(\mathrm{T}=298 \mathrm{~K},\left[\mathrm{Cu}^{2+}\right] / 3=0.05 \mathrm{mM},[\mathrm{dtbc}]_{0}=1.8 \mathrm{mM}\right)$.

csak a háromszorosan deprotonált, azaz három pirazolát-hidat tartalmazó komplex tekinthető katalitikus szempontból aktívnak. Ez stabil terner komplexet képez a pirokatechinát dianionnal, és egy intramolekuláris elektrontranszfer révén valósul meg az oxidáció. Majd a termék disszociációja után a dioxigén visszaoxidálja a réz(I) centrumokat. Minthogy az egymagvú komplexek inaktívak, feltételezésünk szerint a középső, még telítetlen koordinációs szférával rendelkező réz alapvető szerepet játszik a szubsztrát megkötésében és oxidációjában.

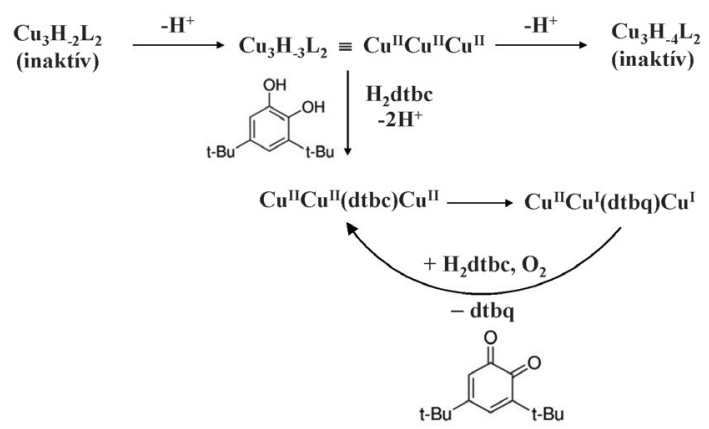

13. Ábra A dtbc katalizált oxidációjának egyszerüsített mechanizmusa

\section{A tripodális peptidek fémkomplexei}

Az elmúlt 10 évben számos hisztidinben gazdag oligopeptidet vizsgáltunk a metalloproteinek fémkötő ill. katalitikus sajátságainak modellezése céljából.9-14 Az enzimek funkcionális modellezésére a peptid komplexek kézenfekvő választásnak tünnek, hiszen elvileg az aktív centrumhoz nagyon hasonló fémion környezet alakítható ki. Ennek ellenére a SOD enzim kivételével ${ }^{10}$ kevés példa akad az irodalomban enzim mimetikus vizsgálatokra. ${ }^{9}$ Ennek oka nagyrészt az, hogy a kisméretü lineáris peptidekkel a fehérjék harmadlagos szerkezete által meghatározott aktív centrumhoz 
hasonló környezet nem, vagy csak speciális esetekben alakítható ki. Bár néhány általunk vizsgált metallopeptid említésre méltó aktivitással bírt, ${ }^{9,10}$ mindegyiknél gond volt a preorganizált szerkezet hiánya. Jellemző példaként említhető a mátrix metalloproteináz 13 (MMP13) minimalista modelljének tekinthető, az enzim fémkötö-fragmensével azonos szekvenciájú, Ac-KAHEFGHSLGLDHSK-NH 2 peptid cink(II) komplexe. ${ }^{13}$ A peptid lényegében tripodális ligandumként viselkedik, hiszen pH 6-7 között, az MMP13 aktív centrumához hasonlóan, a fémion 3 imidazol-gyürü által koordinált, sőt a nukleofil reaktáns $\mathrm{Zn}-\mathrm{OH}^{\text {? }}$ egység is a natív enzimmel azonos pH-tartományban képződik (14. ábra). Ennek ellenére mind a peptid cink-affinitása, mind a komplex hidrolitikus hatása messze elmarad a natív enzimétől.

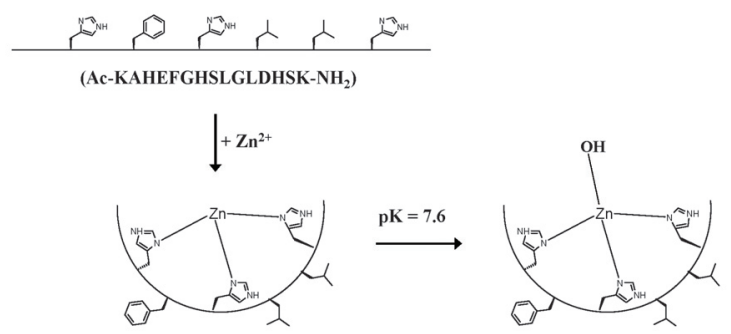

14. Ábra Az Ac-KAHEFGHSLGLDHSK-NH 2 peptid cink(II) komplexeinek sematikus szerkezete

Fenti problémák elkerülése miatt, figyelmünk a tripodális peptidek irányába fordult. Azt reméltük, hogy ezek többé-kevésbé preorganizált szerkezete segíthet az enzimek aktív centrumához hasonló környezet, pl. egymáshoz képest megfelelően pozícionált fémcentrumok kialakításában. E célból tren és nitrilotriecetsav (nta) platformokból kiindulva előállítottunk két hisztidin-tartalmú tripodális pszeudopeptidet (His3tren $\left(\mathbf{L}^{\mathbf{8}}\right)$ és ntaHis3 $\left(\mathbf{L}^{\mathbf{9}}\right)$, ld. 1. séma). Az első esetben a hisztidinek N-terminális, a másodikban C-terminális pozícióban találhatóak, ami alapvetően eltérő koordinációs kémiai sajátságot eredményez réz(II) jelenlétében. A tren-származék $\left(\mathbf{L}^{\mathbf{8}}\right)$ esetén ekvimoláris oldatokban és a semleges $\mathrm{pH}$ tartományban bisz-hisztaminszerü koordinációval rendelkező komplexek képződnek. Ugyanakkor az nta-alapú ligandumnál ( $\left.\mathbf{L}^{\mathbf{9}}\right)$ széles pH-tartományban egy a glicil-hisztidinhez hasonló szerkezet ${ }^{16}$ alakul ki (15. ábra). Mindkét esetben szabad donorcsoportok állnak rendelkezésre további fémionok megkötésére, így fémion felesleg mellett $3 / 2$ illetve $2 / 1$ fém/ligandum arányú komplexek képződnek.

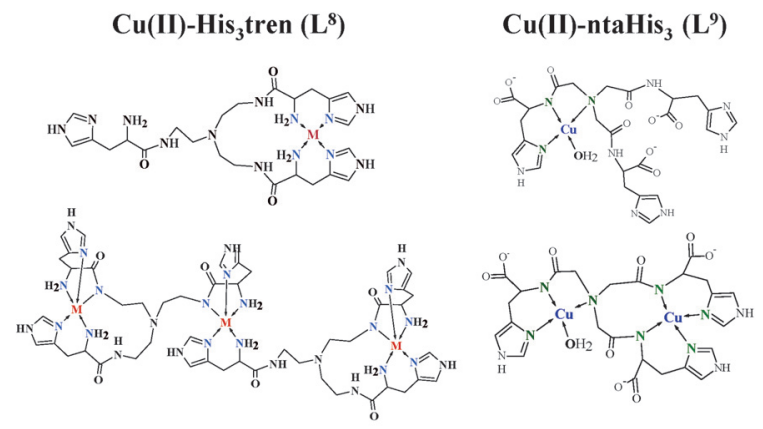

15. Ábra $\mathrm{A} \mathrm{Cu}(\mathrm{II})-\mathbf{L}^{8}$ és $-\mathbf{L}^{9} 1 / 1$ és $3 / 2$ fém/ligandum arányú rendszerekben $\mathrm{pH}$ 8-9 körül domináns komplexek sematikus szerkezete
Magasabb pH-n, ahogy az a peptidek rézkomplexeinél szokásos, az amid-nitrogének is részt vesznek a koordinációban.

A koordinációs kémiai sajátságok tisztázása után vizsgáltuk a réz(II)-L $\mathbf{L}^{\mathbf{8}} / \mathbf{L}^{\mathbf{9}}$ rendszerek pirokatechin oxidáz aktivitását. Előzetes eredményeinkből kitünt, hogy a többmagvú komplexek mindkét esetben nagyobb aktivitással bírtak, de csak az nta-származéknál $\left(\mathbf{L}^{\mathbf{9}}\right)$ volt jelentős ez az aktivitás növekedés az egymagvú komplexekhez képest. A 16. ábra a telítési kinetikai eredményeket hasonlítja össze az adott rendszerre optimális körülmények között. A Michaelis-Menten modell alapján számolt paraméterek (16. ábra) szerint az nta-származék $\left(\mathbf{L}^{\mathbf{9}}\right)$ kétmagvú rézkomplexe $\mathrm{kb}$. hatszor hatékonyabb mint a hárommagvú $\mathrm{Cu}(\mathrm{II})-\mathbf{L}^{\mathbf{8}}$ komplex. Eredményeink szerint ez jórészt annak köszönhetö, hogy a hárommagvú $\mathrm{Cu}(\mathrm{II})-\mathbf{L}^{\mathbf{8}}$ komplexben a fémcentrumok nagyobb távolsága miatt azok izoláltan müködnek, míg a kétmagvú komplex kisebb réz-réz távolsága a fémcentrumok közötti kooperációt is lehetővé teszi.

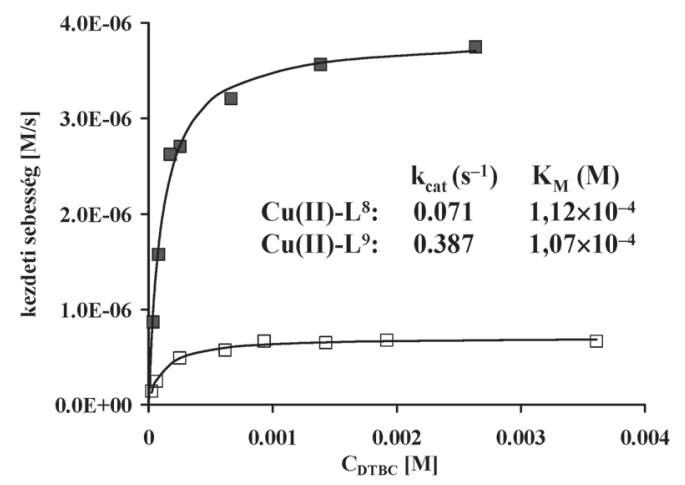

16. Ábra $\mathrm{A} \mathrm{H}_{2} \mathrm{dtbc}$ oxidáció kezdeti sebességének függése $\mathrm{a} \mathrm{H}_{2} \mathrm{dtbc}$ koncentrációjától a $\mathrm{Cu}(\mathrm{II})-\mathbf{L}^{\mathbf{8}} / \mathbf{L}^{\mathbf{9}}$ rendszerekben. $\mathrm{Cu}(\mathrm{II})-\mathbf{L}^{\mathbf{8}}\left(\mathbf{\square},[\mathrm{Cu}] /\left[\mathbf{L}^{7}\right]=\right.$ $\left.3 / 1,\left[\mathbf{L}^{\mathbf{8}}\right]_{\mathrm{tot}}=10^{\square 5} \mathrm{M}, \mathrm{pH}=7.8\right) ; \mathrm{Cu}(\mathrm{II})-\mathbf{L}^{\mathbf{9}} \mathbf{\mathbf { }},[\mathrm{Cu}] /\left[\mathbf{L}^{\mathbf{8}}\right]=2 / 1,\left[\mathbf{L}^{9}\right]_{\mathrm{tot}}=$ $10^{\text {व5 }} \mathrm{M}, \mathrm{pH}=9.0$ )

\section{5. Összefoglalás}

Egyszerü tripodális platformok (tren, tach, nta) moduláris funkcionalizálása lehetőséget teremt a koordinációs kémiai sajátságok, a képződő komplexek összetételének, szerkezetének, stabilitásának finomhangolására. Ezek ugyanakkor alapvetően meghatározzák a komplexek katalitikus sajátságait, így tervezhetővé válnak olyan enzimszerü tulajdonságok, mint a katalitikus aktivitás pH-függése, a katalitikus fémion megkötődésének alloszterikus kontrollja, vagy a fémionok kooperációja.

\section{Hivatkozások}

1. Itoh, T.; Hisada, H.; Sumiya, T.; Hosono, M.; Usui, Y.; Fujii, Y., J. Inorg. Biochem. 2007 101, 348-361. http://dx.doi.org/10.1016/j.jinorgbio.2006.10.011

2. Fujii, Y.; Kiss, T.; Gajda, T.; Tan, X.S.; Sato, T.; Nakano, Y.; Hayashi, Y.; Yashiro, M., J. Biol. Inorg. Chem., 2002, 7, 843-851 https://doi.org/10.1007/s00775-002-0368-9

3. Krämer, R.; Gajda, T.; "Functional Model Complexes for Dinuclear Phosphoesterase Enzymes", in Perspectives on Bioinorganic Chemistry; ed. Hay, R. W.; Dilwoth, J. R.; Nolan, K., JAI Press Inc.: Stamford, Connecticut, 1999, vol. 4, pp 207-240. https://doi.org/10.1016/s1062-239x(99)80032-7 
4. Hegetschweiler, K., Chem. Soc. Rev., 1999, 28, 239-249. https://doi.org/10.1039/a802638f

5. Gajda, T.; Düpre, Y.; Török, I.; Harmer, J.; Schweiger, A.; Sander, J.; Kuppert, D.; Hegetschweiler, K., Inorg. Chem. 2001, 40, 4918?4927. https://doi.org/10.1021/ic0005902

6. Jancsó, A.; Mikkola, S.; Lönnberg, H.; Hegetschweiler, K.; Gajda, T., Chem. Eur. J., 2003, 9, 5404-5415. https://doi.org/10.1002/chem.200305149

7. Jancsó, A.; Mikkola, S.; Lönnberg, H.; Hegetschweiler, K.; Gajda, T., J. Inorg. Biochem., 2005, 99, 1283-11293. https://doi.org/10.1016/j.jinorgbio.2005.02.027

8. Jancsó, A.; Török, I.; Hegetschweiler, K.; Gajda, T.; ARKIVOC 2009, Part 3, 217-224.

9. Paksi, Z.; Jancsó, A.; Jakab, N.; Gyurcsik, B.; Rockenbauer, A.; Gajda, T., Dalton Trans., 2005, 19, 3187-3194. http://dx.doi.org/10.1039/b507655b

\section{Biomimetic complexes of polidentate tripodal ligands}

In order to create highly efficient low molecular weight enzyme mimics, recently we synthesized several new tris(2-aminoethyl)amin (tren), cis,cis-1,3,5-triaminocyclohexane (tach) and nitrilotriacetic acid (nta) based tripodal ligands possessing quite different coordination properties. From the enzyme mimetic point of view, the tripodal ligands have several advantages over the linear and even macrocyclic ligands. These ligands have enhanced chelate effect, and preorganized structure (reduced number of relevant binding conformations) resulting higher stability of the complexes. Tripodal ligands enforce 'facial' metal binding and (partly) enclose the metal ion, similarly to metalloenzymes. By adequate substitution of the tripodal platform it is possible to fine tune the metal binding ability by varying the number and type of donor atoms. Designed substituents may also directly influence the steric environment around the metal centre or may provide additional metal binding site, inducing metal-metal cooperation during the catalytic cycle.

Earlier, we reported that the copper(II) complexes of cis,cis-1,3,5-triaminocyclo-hexane (tach, $\mathbf{L}^{\mathbf{1}}$ ) is an efficient metallopeptidase mimic. Tach is an excellent platform to create tailored properties of metal complexes, too. The dinuclear $\mathrm{Cu}$ (II) and $\mathrm{Zn}$ (II) complexes of cis,cis-1,3,5-tris (dimethylamino)-2,4,6trihydroxycyclohexane (tdci, $\mathbf{L}^{2}$ ) provide outstanding rate acceleration for the hydrolysis of phosphodiesters, but possess considerably lower efficiency toward the hydrolysis of phosphomonoesters. The related monomethylated ligand (tmci, $\mathbf{L}^{3}$ ) is less rigidly preorganized due to the decreased intraligand repulsions between the methylamino groups, which strongly influences the properties of its metal complexes. Indeed, in contrast to tdci, the dinuclear $\mathrm{Cu}$ (II) complexes of tmci do not promote the hydrolysis of phosphodiesters, but allow selective cleavage of phosphomonoesters.

We also prepared several N-substituted derivatives of tren, tach and nta. Since the pyridine nitrogens in $\mathbf{L}^{4}$ and $\mathbf{L}^{5}$ are not able to coordinate the metal ion bound to the tripodal units, the ML
10. Paksi, Z.; Jancsó, A.; Pacello, F.; Nagy, N.V.; Battistoni, A.; Gajda, T., J. Inorg. Biochem., 2008, 102, 1700-1710. https://doi.org/10.1016/j.jinorgbio.2008.04.007

11. Kolozsi, A.; Jancsó, A.; Nagy, N.V.; Gajda, T., J. Inorg. Biochem. 2009, 103, 940-947. https://doi.org/10.1016/j.jinorgbio.2009.04.006

12. Árus, D.; Jancsó, A.; Szunyogh, D.; Matyuska, F.; Nagy, N.V.; Hoffmann, E.; Körtvélyesi, T.; Gajda, T., J. Inorg. Biochem. 2012, 106, 10-18. https://doi.org/10.1016/j.jinorgbio.2011.09.029

13. Árus, D.; Nagy, N.V.; Dancs, Á.; Jancsó, A.; Berkecz, R.; Gajda, T., J. Inorg. Biochem. 2013, 126, 61-69. https://doi.org/10.1016/j.jinorgbio.2013.05.015

14. Árus, D.; Dancs, Á.; Nagy, N.V.; Gajda, T., Dalton Trans., 2013, 42, 12031-12040. https://doi.org/10.1039/c3dt50754h

complexes have similar structure to the corresponding complexes of tren and tach. At higher $\mathrm{pH}$ mixed hydroxo complexes are formed. The presence of pyridine rings in $\mathbf{L}^{\mathbf{5}}$ hinder the formation of the dihydroxo bridged dinuclear complex observed in the $\mathrm{Cu}(\mathrm{II})$-tach system. The species $\mathrm{CuL}^{5}(\mathrm{OH})$ is an active catalyst for the hydrolysis of phosphodiesters.

Since the pyrazole nitrogens in $\mathbf{L}^{6}$ and $\mathbf{L}^{7}$ ligands are in chelating positions, these ligands form stable $5 / 6 \mathrm{~N}$ coordinated ML complexes with $\mathrm{Cu}$ (II) and $\mathrm{Zn}(\mathrm{II})$. In the cases of both ligands, the pyrrole nitrogens of the $\mathrm{Cu}$ (II)-bound pyrazole rings create a further metal binding site via pyrazolato bridges, and thus tricopper complexes are formed. The formation of $\mathrm{Cu}_{3} \mathrm{H}_{4} \mathrm{~L}_{2}$ species even in equimolar solution is noteworthy, and can be regarded as a $\mathrm{pH}$-driven spontaneous self-assembly. In the crystal structure of $\left[\mathrm{Cu}_{3} \mathrm{H}_{4}\left(\mathbf{L}^{6}\right)_{2}\right]\left(\mathrm{ClO}_{4}\right)_{2} 3 \mathrm{H}_{2} \mathrm{O}$ the two outer copper(II) are $5 \mathrm{~N}$ coordinated in square pyramidal geometry, while the central copper(II) is bound to four deprotonated pyrrolic nitrogens in tetrahedral geometry. The tricopper complexes of both ligands are highly active catecholase mimics working at surprisingly low $\mathrm{pH}$ (5-7). Since the mononuclear $\mathrm{CuL}^{6 / 7}$ species do not show catecholase activity, we assume that the central tetrahedral copper(II) ion has fundamental role in the catechol binding and oxidation.

The presence of $\mathrm{C}$ - and N-terminal histidines in the two tripodal peptide derivatives $\left(\mathbf{L}^{8}\right.$ and $\left.\mathbf{L}^{9}\right)$ results in basically different structures in their copper(II) complexes. In the neutral $\mathrm{pH}$ range, the mononuclear $\mathrm{Cu}(\mathrm{II})$ complexes of $\mathbf{L}^{\mathbf{8}} / \mathbf{L}^{\mathbf{9}}$ have Gly-His-like/bis-histamine-like coordination mode, respectively. In both cases the loosely bound or non-coordinating donor groups create a further metal binding site, therefore dinuclear $\left(\mathbf{L}^{\mathbf{9}}\right)$ and trinuclear $\left(\mathbf{L}^{\mathbf{8}}\right)$ complexes are formed. Above $\mathrm{pH} 7$, the oligonuclear complexes of both $\mathbf{L}^{\mathbf{8}}$ and $\mathbf{L}^{\mathbf{9}}$ have efficient catecholase-like activity, but the cooperation of the metal centres is operating only in the latter case. 